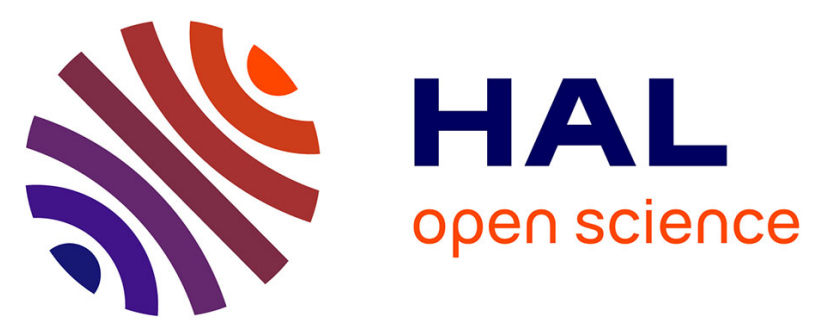

\title{
Comparative Physicochemical Analysis of Pulp Stone and Dentin
}

Fleur Berès, Juliane Isaac, Ludovic Mouton, Stephan Rouzière, Ariane Berdal, Stéphane Simon, Arnaud Dessombz

\section{To cite this version:}

Fleur Berès, Juliane Isaac, Ludovic Mouton, Stephan Rouzière, Ariane Berdal, et al.. Comparative Physicochemical Analysis of Pulp Stone and Dentin. Journal of Endodontics, 2016, 42 (3), pp. 432438. 10.1016/j.joen.2015.11.007 . hal-01312900

\section{HAL Id: hal-01312900 https://hal.sorbonne-universite.fr/hal-01312900}

Submitted on 9 May 2016

HAL is a multi-disciplinary open access archive for the deposit and dissemination of scientific research documents, whether they are published or not. The documents may come from teaching and research institutions in France or abroad, or from public or private research centers.
L'archive ouverte pluridisciplinaire HAL, est destinée au dépôt et à la diffusion de documents scientifiques de niveau recherche, publiés ou non, émanant des établissements d'enseignement et de recherche français ou étrangers, des laboratoires publics ou privés. 


\section{Comparative Physicochemical Analysis of Pulp Stone and Dentin.}

Fleur Berès ${ }^{1,2}$, Juliane Isaac ${ }^{2,3,4}$, Ludovic Mouton ${ }^{5}$, Stephan Rouziere ${ }^{6}$, Ariane Berdal ${ }^{1,3}$, Stéphane Simon ${ }^{1,3,7^{*}}$, Arnaud Dessombz ${ }^{1,3}$

1-Laboratory of Molecular Oral Pathophysiology, INSERM UMRS 1138, Team Berdal, Cordeliers Research Center, Pierre and Marie Curie University.

2- UFR d'odontologie, Pais Descartes University - Paris 5, France

3-UFR d'Odontologie, Paris Diderot University - Paris 7, Paris, France

4-Laboratory of Morphogenesis Molecular Genetics, Department of Developmental and Stem Cells Biology, Institut Pasteur, CNRS URA 2578, Paris, France.

5- ITODYS, UMR 7086 CNRS, Université Paris Diderot, Sorbonne Paris Cité, F-75205 Paris Cedex 13, France

6- Laboratoire de Physique des Solides, Université Paris-Sud, CNRS, UMR 8502, F-91405 Orsay Cedex, France.

7- Hopital de la Pitié Salpêtrière, Service d’Odontologie, Paris, France

* Corresponding author: Dr Stéphane SIMON, UFR d'odontologie, 5 rue de Garancière, 75006 Paris

\section{Acknowledgements}

The authors deny any conflict of interest. Dr Fleur Beres is financially supported with a CIFRE national grant (2014-0428). The SU-70 Hitachi SEM-FEG instrumentation was provided by the IMPC FR2482 (Institut des Matériaux de Paris Centre) and financially supported by the C'Nano projects of the Région lle-de-France. 


\section{Figure 1 \\ Click here to download high resolution image}

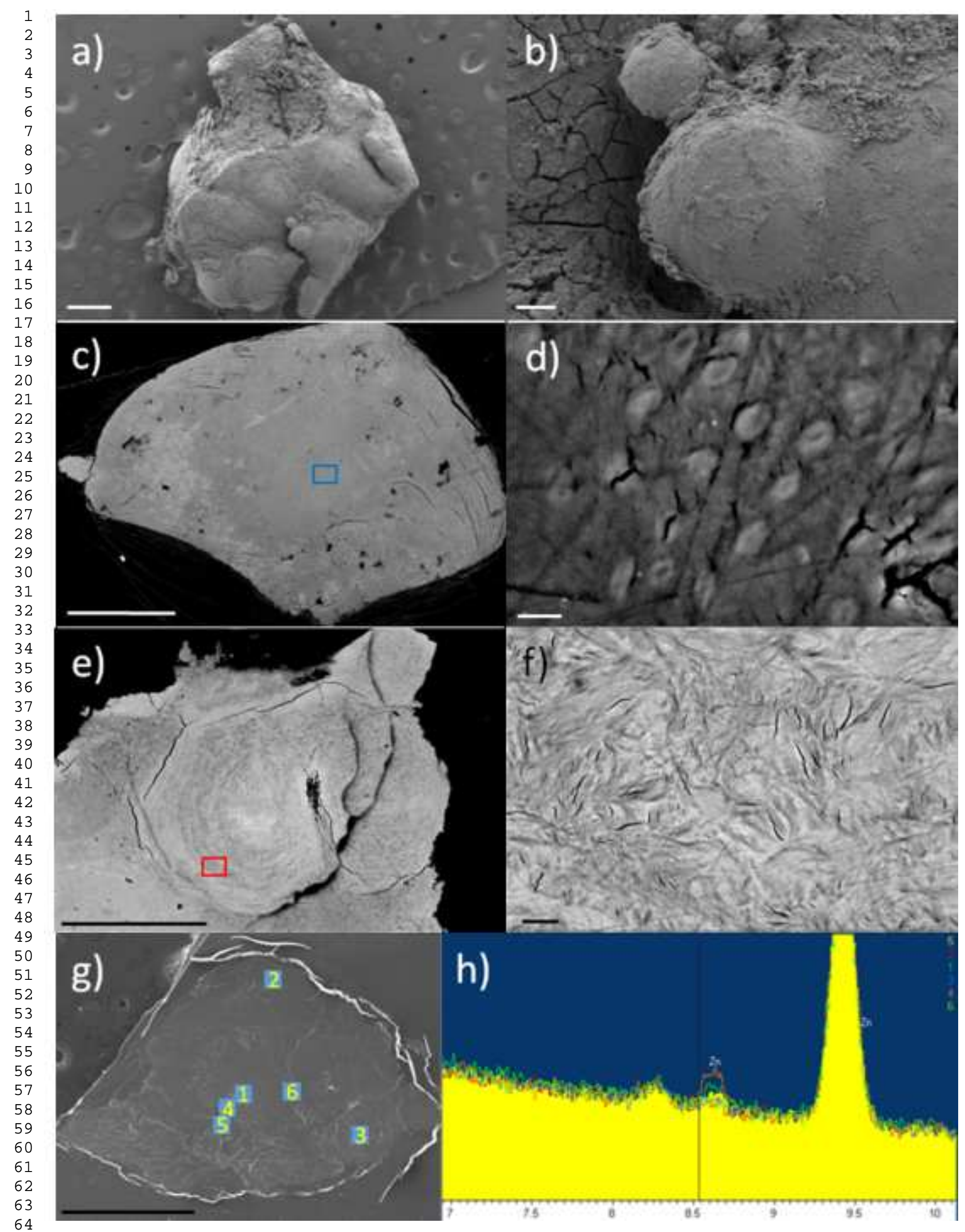


Click here to download high resolution image

a)

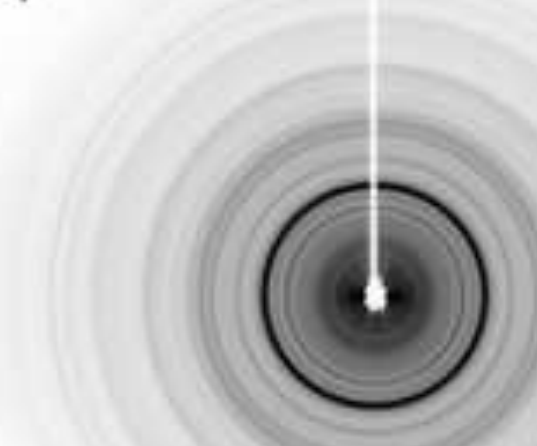

c)

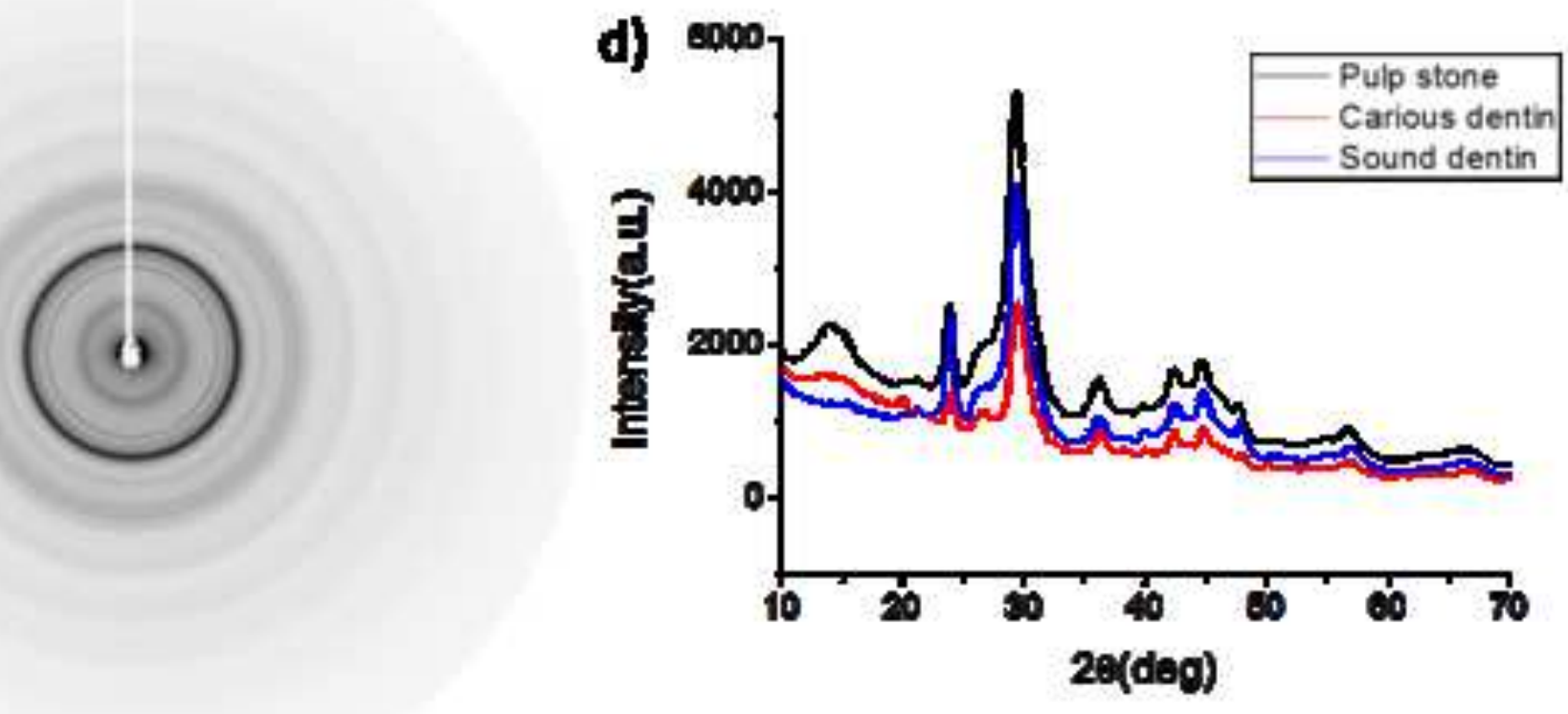

b)

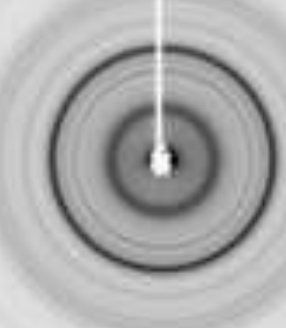


Click here to download high resolution image

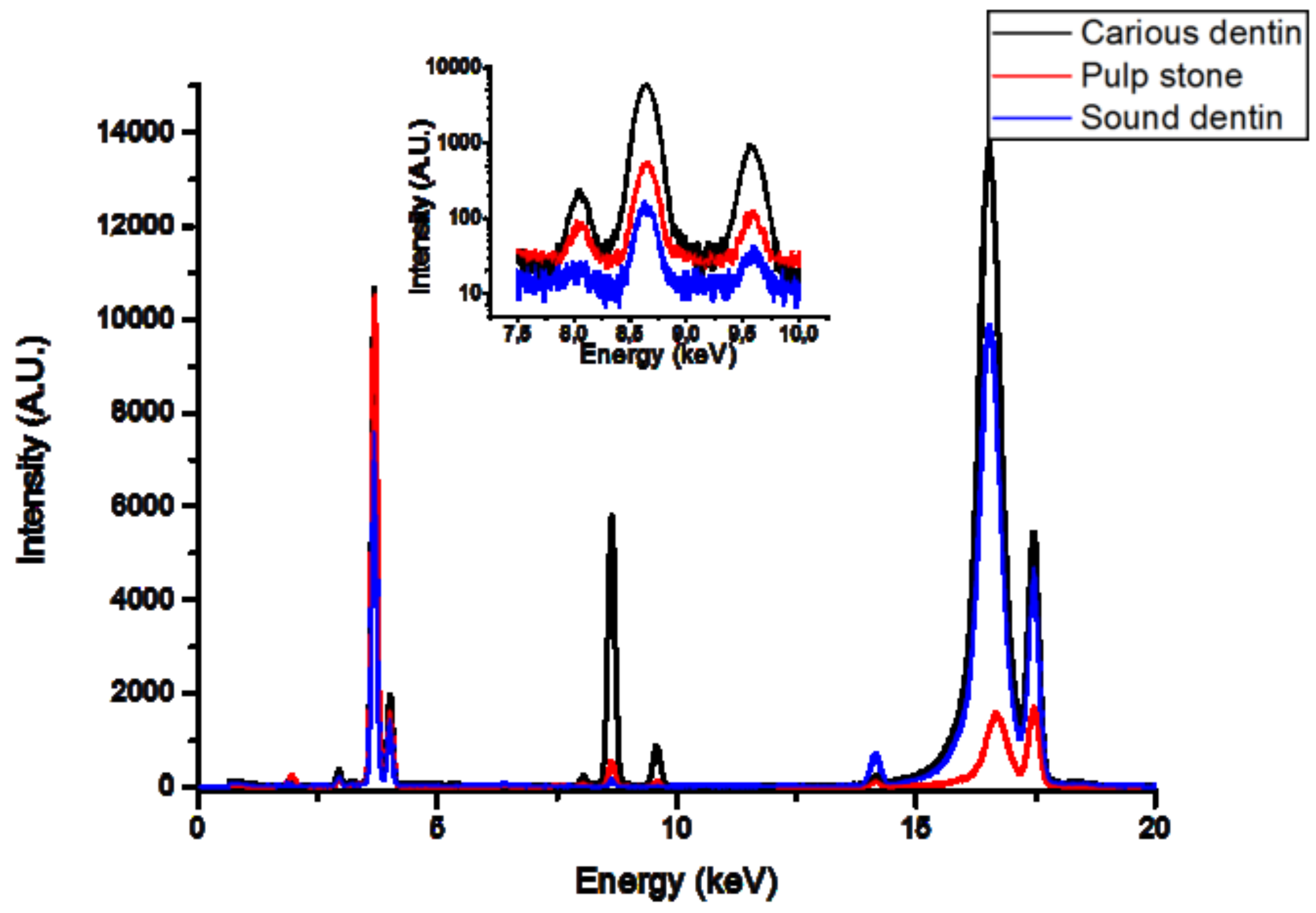


Click here to download high resolution image

1
2
3
4
5
6
7
8
9
10
11
12
13
14
15
16
17
18
19
20
21
22
23
24
25
26
27
28
29
30
31
32
33
34
35
36
3
38
39
40
4
4
4
4
4
4
4
4
4
4

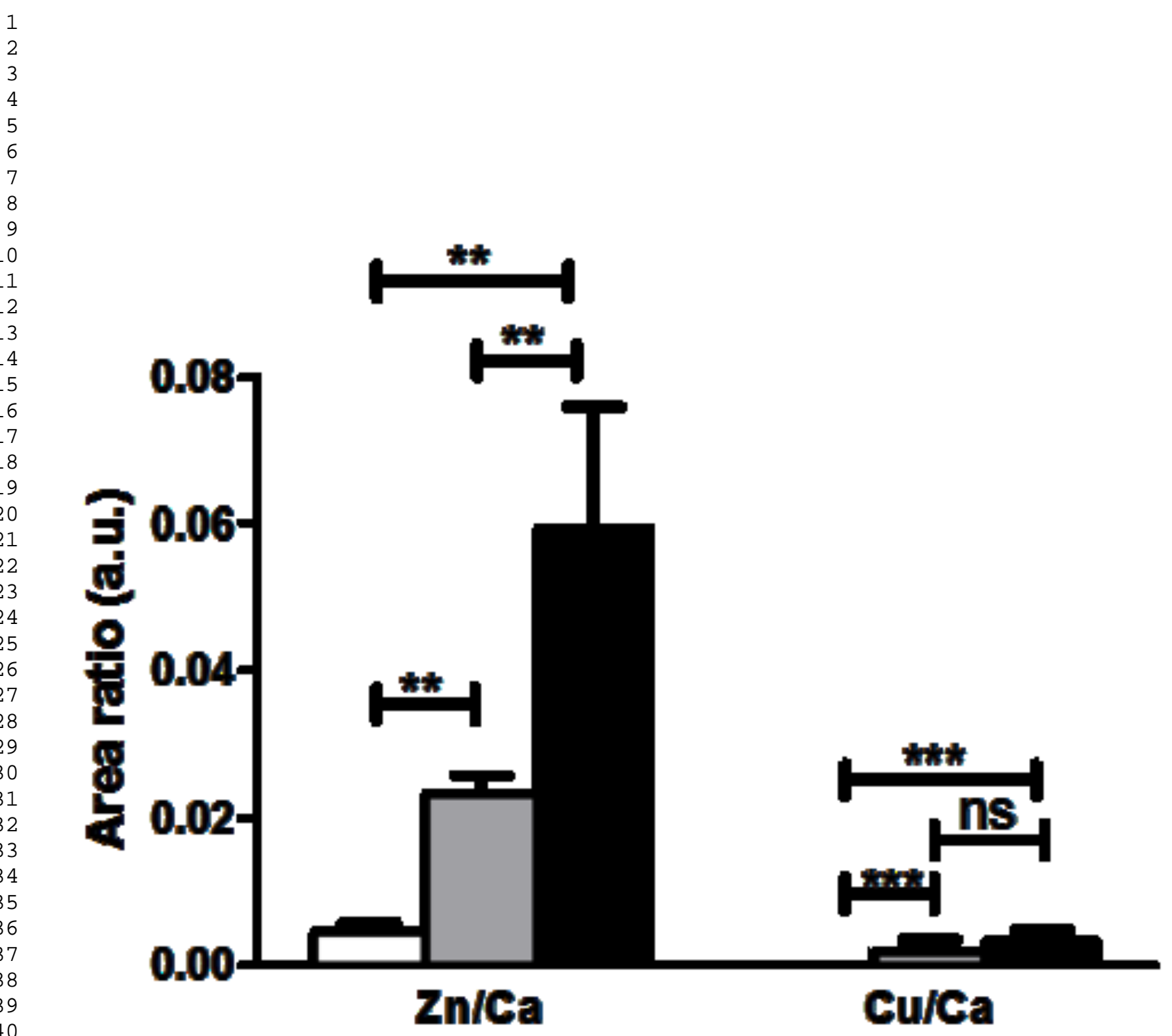

$\square$ Sound dentin $\square$ Carious dentin Pulp stone 


\section{Highlights :}

- to investigate the physicochemical properties of health dentine and pulp stones

- Pulp stones showed heterogeneous structure and chemical composition

- Pulpal cells produce unstructured apatitic mineralizations containing abnormally high $\mathrm{Zn}$ and Cu levels.

- the high concentrations of these elements detected in pulp stones, may be related to elevated superoxide dismutase enzyme activity 


\begin{abstract}
Introduction: Odontoblasts are responsible for the synthesis of dentin throughout the life of the tooth. Tooth pulp tissue may undergo a pathological process of mineralization, resulting in formation of pulp stones. While the prevalence of pulp stones in dental caries is significant, their development and histopathology are poorly understood and their precise composition has never been established. The aim of the present study was to investigate the physicochemical properties of the mineralized tissues of teeth to elucidate the pathological origin of pulp stones.
\end{abstract}

Methods: Areas of carious and healthy dentin of eight decayed teeth intended for extraction were analyzed and compared. In addition, six pulp stones were recovered from five teeth requiring root canal treatment. The samples were embedded in resin, sectioned and observed by scanning electron microscopy and energy-dispersive spectroscopy. X-ray diffraction was performed to identify phases and crystallinity. X-ray fluorescence provided information on the elemental composition of the samples.

Results: Pulp stones showed heterogeneous structure and chemical composition. X-ray diffraction revealed partially carbonated apatite. X-ray fluorescence identified $\mathrm{P}, \mathrm{Ca}, \mathrm{Cu}, \mathrm{Zn}$, and $\mathrm{Sr}$ within dentin and pulp stones. $\mathrm{Zn}$ and $\mathrm{Cu}$ concentrations were higher in pulp stones and carious dentin compared to healthy dentin.

Conclusions: Pulpal cells produce unstructured apatitic mineralizations containing abnormally high $\mathrm{Zn}$ and $\mathrm{Cu}$ levels. 


\section{Introduction}

Dental pulp and dentin act as a single physiological unit, usually named the dentinpulp complex. At the periphery of the dental pulp, dentinogenesis is the main biological activity of the odontoblasts, which are also mechanosensitive and immunocompetent cells (1). Odontoblasts are a postmitotic cells, but remain active throughout their lifetime. Odontoblasts secrete primary dentin during early tooth development, and this creates the first pattern of the tooth. When the tooth becomes functional, secondary dentinogenesis replaces primary dentinogenesis as the same odontoblasts secrete dentin at a lower rate (2).

Tertiary dentinogenesis is a third process mediated by odontoblasts and may be categorized into two types: reactionary and reparative. Reactionary dentinogenesis is the process whereby dentin is secreted in response to a local stimulus that reactivates the resting odontoblasts (3). Reparative dentinogenesis occurs when odontoblast cells die, thus initiating a complex regenerative process that allows the formation of reparative dentin following recruitment of progenitor cells, their differentiation into odontoblast-like cells, and activation of mineralized tissue secretion. These two types of pulp responses are quite well described (4).

In addition to dentinogenesis in its varied forms, the occurrence of central pulpal calcifications has been reported in several clinical observational studies (5). Pulp stones are usually clinically identified on routine radiographic examination and in close association with deep restorations or repeated mild tooth injury over time. The frequency of occurrence of such calcifications is unclear. Reported rates vary from $4 \%$ (6) to $78 \%$ (7). It is commonly accepted that at least $50 \%$ of all teeth present one or more mineralized stones (8). Pulp stones have been observed in the dental pulp in all age groups, albeit with increased frequency in older age groups and insulted pulps (9).

The etiological factors in pulp calcifications formation are not well understood. Several mechanisms have been proposed (8). Calcifications may develop around an area of damaged pulp tissue (e.g. degenerating cells, blood thrombi or collagen fibrils). Calcium phosphate crystals may also be deposited within the mineralizing 
cells. Calcifications replace the normal components of the pulp and might generate an inflammatory environment (8).

Different forms of pulp stones can be found: entrapped, adherent or free within the pulp tissue (10). Their diameters vary from $50 \mu \mathrm{m}$ to several millimeters (11). These calcifications may fully seal the pulp chamber volume and thereby complicate endodontic treatment. The calcifications are described as true (resembling dentin), false (composed of localized masses of calcified material) or diffuse (often found near blood vessels) (12). Their mineral phase consists of typical carbonated hydroxyapatites (13); however, their precise composition has never been established (14).

More knowledge on the crystallographic structure and physicochemical composition of pulp stones would contribute to a better understanding of their formation and the pathogenesis of pulp calcification. In normal and ectopic mineralizations, the accuracy of physicochemical analysis has been demonstrated $(15,16,17,18)$. The present study aimed to provide a detailed comparative description of the mineral phase that is in the pulpal calcification. To this end we used X-ray diffraction (XRD) and X-ray fluorescence (XRF) spectrometry and compared the mineral composition of pulp stones with their ultrastructure by using healthy $(19,20)$ and carious dentin (21) of the same teeth as references.

\section{Materials and Methods}

\section{Collection of Samples}

\section{Healthy and carious dentin}

Human, freshly extracted permanent molars were obtained from patients requiring extractions after consulting in the emergency department (Hopital de la Pitié Salpêtrière). Selected teeth were unrestored but presented carious diseases with either occlusal or proximal active lesions. A carious zone and a healthy zone (free from caries) were isolated from each specimen. Caries involving more than half of the crown dentin (on a periapical radiograph) were excluded from the study. Eight teeth were selected from eight different patients (three females and five males, aged from 20 to 73 years old). 


\section{Pulpal calcifications}

Pulp stones were retrieved from teeth scheduled for endodontic treatment. In total, six pulpal calcifications, whose sizes ranged from $1.2 \mathrm{~mm}$ to $2.5 \mathrm{~mm}$ (mean size 1.7 $\mathrm{mm} \pm 0.4 \mathrm{~mm}$ ). They were obtained from five patients (three females and two males, aged from 37 to 68 years fold).

Human sample collection complied with the Helsinki Declaration. According to French law on human research (Law 2007-1110, article 1211-2), tooth and pulpal sample collection (surgical waste) is allowed unless a patient objects; all patients were informed of the use of the samples and gave their consent.

\section{Preparation of samples}

After collection, specimens were gently cleaned and exogenous material removed. Samples were rinsed with a phosphate buffered saline (PBS) solution at pH 7.4 (Invitrogen) and fixed with $4 \%$ formaldehyde in the same PBS buffer (Electron Microscopy Sciences, Hatfield, PA). Samples were then dehydrated in a graded series of ethanol solutions ( $75 \%$ for two days, $90 \%$ for two days, and $100 \%$ for two more days). Samples were embedded into light cured acrylate-resin (Technovit 7200 VLC, Heraeus Kulzer, Hanau, Germany), or not (for surface characterization).

Blocks were cut into 150- $\mu$ m-thick slices using a low-speed diamond saw (Isomet Low Speed Cutter, Buehler, Düsseldorf, Germany) under constant water irrigation. Surfaces of samples were polished by using increasing grit polisher disks.

\section{Scanning Electron Microscopy (SEM)}

Each sample was sputter-coated with a 5-nm layer of platinum (SC7640 sputter coater, Quorum Technologies, Guelph, ON, Canada). A SUPRA 40 scanning electron microscope (Carl Zeiss, Oberkochen, Germany) was used to observe the microstructure. This field-effect gun microscope operates a 0.5 to $30 \mathrm{kV}$. Observations were made using an Everhart-Thornley secondary electron (SE) detector at $5 \mathrm{keV}$. Polished section samples were observed with a backscattering electron (BSE) detector at $15 \mathrm{keV}$.

\section{Energy-Dispersive Spectroscopy (EDS)}


Sputter-coated samples were prepared. Imaging and microanalysis were performed on an SU-70 Hitachi SEM-FEG and an X-Max $50 \mathrm{~mm}^{2}$ Oxford EDX detector.

\section{X-Ray Diffraction (XRD)}

Phase identification and crystallinity of the dental mineral part were evaluated by $X$ ray diffraction. Experiments were carried out with a molybdenum rotating anode $\mathrm{X}$-ray generator (RIGAKU RUH2R) coupled with multilayer W/Si optics delivering a focalized and monochromated $(\lambda=0.711 \AA) X$-ray beam of $800 \mu \mathrm{m} \times 1 \mathrm{~mm}$ size onto the sample. X-ray images were recorded with a MAR345 (@MAR Research) detector placed at of a distance of $200 \mathrm{~mm}$ from the sample. Acquisition time for each measurement was $30 \mathrm{~min}$. Diffraction diagrams were obtained by processing radial intensity integration of each image, and then the positions of the diffraction peaks were compared with reference files from the Joint Committee on Powder Diffraction Standards (JCPDS) database.

\section{X-Ray Fluorescence (XRF)}

X-ray fluorescence allows precise determination of the elemental composition of the sample. Experiments were carried out with a molybdenum rotating anode X-ray generator (RIGAKU RU200) coupled with multilayer W/Si optics delivering a focalized and monochromated $(\lambda=0.711 \AA)$ X-ray beam of $150 \mu \mathrm{m} \times 150 \mu \mathrm{m}$ size. Fluorescence spectra were measured with an energy dispersive detector (SDD detector @Ketek), with a time acquisition of 1500 s each. XRF analysis was performed with PyMca software (22).

\section{Statistical Analysis}

Statistical comparisons were made using the Wilcoxon-Mann-Whitney test (GraphPad Prism). Data are expressed as the mean \pm standard deviation $(m \pm S D)$.

\section{Results}


Representative SEM images of the samples are shown in Figure 1, obtained using

Two-dimensional (2D) XRD patterns for healthy (a), carious dentin (b) and pulp stone (c) are illustrated in Figure 2. Diffraction diagrams of the three samples showed similar Debye ring patterns. Phase identification was performed by comparison with reference data (JCPDS 9-432) and led to the identification of partially carbonated apatite. XRD diagrams (Fig. 2d) were similar in the healthy, carious dentin and pulp stone samples, with only some minor differences in peak intensities and width. No texture could be noted, which indicates that no preferential crystalline orientation exists in these samples. However, the shoulder marked with an asterisk (at 2-theta = $26.78^{\circ}$ ) in the pulp stone sample suggests a modified crystallite morphology and variation along (202) the crystallographic direction. Each ring was quite intense and thin, indicative of high crystallinity. Diffuse halos at small angles can be seen, but they were not considered further as they are presumed to have been caused by diffusion of the acrylate resin.

X-ray fluorescence (XRF) spectra identified $\mathrm{P}, \mathrm{Ca}, \mathrm{Cu}, \mathrm{Zn}$ and $\mathrm{Sr}$ within dentin and pulp stones (Fig. 3). The presence of $\mathrm{Ca}$ and $\mathrm{P}$ further supports that the mineral 
phase is a calcium phosphate, in accordance with the XRD results shown in Figure 2. As observed here, $\mathrm{Sr}$ is also commonly found in biological apatite as a substitute for $\mathrm{Ca}$ (23). Contributions of $\mathrm{Zn}$ and $\mathrm{Cu}$ (shown in the inset of Fig. 3) varied depending on the dentin site and status, being higher in pulp stone and carious dentin than in healthy dentin.

Comparisons of mineral composition between samples were performed by calculating their respective elemental ratios (Fig. 4). The XRD experiments showed that the mineral phase in each sample was apatite. Ca was used as an internal reference element to compare the composition of the trace elements $\mathrm{Cu}$ and $\mathrm{Zn}$. Each XRF spectrum was analyzed with PyMCA software to obtain the area under the fluorescence peak curve (AUC) of each identified element. AUCs of each element of interest were divided by the AUC value of $\mathrm{Ca}$. Mean values of each ratio for all samples are shown with the standard deviation in Figure 4. Significantly higher levels of $\mathrm{Zn}$ were found in pulp stones and carious dentin compared to healthy dentin $(P<0.01)$. Moreover, the $\mathrm{Zn}$ level was significantly higher in pulp stone compared to carious dentin $(\mathrm{P}<0.01)$. Whereas $\mathrm{Cu}$ was almost undetectable in healthy dentin $\left(6.7 \times 10^{-5} \pm 0.7 \times 10^{-5}\right.$, limit of detectability), it was significantly increased in both carious dentin and pulp stones $\left(p<0.001,1.7 \times 10^{-3} \pm 2.6 \times 10^{-4}\right.$ for carious dentin and $3.0 \times 10^{-3} \pm 1.7 \times 10^{-4}$ for pulp stone).

\section{Discussion}

Pulp stones arise as a pulp response to mild injury (9). The aetiology of pulp calcifications has been attributed to long-standing local irritants, such as caries, wasting diseases, pulp-capping procedures, healed fractures, tooth injury restorations, periodontal conditions and orthodontic tooth movements. In young adults, pulp stone have been significantly associated with carious and/or restored teeth suggesting that chronic pulp irritation might lead to pulp stone formation (Rantikar 2002). The other reported causes include idiopathic factors, fluoride supplements, hypervitaminosis $\mathrm{D}$ or a possible genetic predisposition $\underline{\text { (dentinogenesis imperfecta and dentinal dysplasia, which may be seen even in }}$ 
unerupted teeth, and aging) (Kansu et al, 2009). With aging, the pulp decreases in

size due to the deposition of secondary/tertiary dentin; this results in favorable conditions for development of pulpal calcifications (Goga et al. 2008). Nevertheless the correlation between aging and pulpal calcifications remains unclear and is still under discussion (Sayed \& Reed in 1968). Of note, in the present study no direct relationship between aging and pulp stones size and composition were noticed, however further investigation is needed to answer this question.

Although epidemiological studies have highlighted their high prevalence $(7,9)$, basic knowledge of the reactionary process that gives rise to pulp stones is still missing. By using peripheral healthy and carious dentin as reference material, we undertook a physicochemical study of pulp stones to explore the clinical hypothesis that they are composed of a dentin-like substance secreted in response to repeated mild inflammation of the pulp.

Our XRD data indicate that apatitic structures are shared by pulp stones, carious and healthy dentins. The general shapes of the diffractograms prove the absence of significant crystallographic differences, as previously reported for dentin $(19,20)$. Some minor differences in width and intensity that we observed suggest morphological differences consistent with the known subtle modifications of stoichiometry in imperfect bioapatites (18). Only apatites of rather good crystallinity were present in pulp stones. This is different from ectopic calcifications, which contain additional mineral phases (16) and apatites of altered crystallinity (17). The shape and absence of texture of the Debye ring patterns we observed for pulp stones are similar to those of dentin and bone (20).

Our SEM investigations underlined the heterogeneity of pulpal mineralization. Whereas, the organization of pulp stones and dentin was similar in restricted areas, supporting the previously proposed dentin-like nature of some pulp stones (10), more encompassing observations at lower magnification highlighted a true difference at the ultrastructural level. SEM imaging evidenced globules of various sizes, formed by fused concentric layers of variable composition. This observation suggests the occurrence of several sites for globule initiation followed by their progressive enlargement and ending with their fusion and entrapment of dentin-like regions within large pulp stone territories. The concentric layers we observed by SEM-BSE are supposed to be related to mineral density and heterogeneity. EDS analysis on the 
brighter areas at the periphery of pulp stones showed no evidence of trace elements, thus supporting a higher mineral density in restricted regions of pulp stone instead of substitution of $\mathrm{Ca}$ by heavy elements. Detection of $\mathrm{Zn}$ by EDS in the darker zones led us to investigate its distribution in more detail. On XRF examination, both $\mathrm{Zn}$ and $\mathrm{Cu}$ were detected specifically in pulp stones and carious dentin. In this respect, whereas Zn presence has already been described in dentin $(24,19,20)$ and bone $(25)$, the combined presence of $\mathrm{Zn}$ and $\mathrm{Cu}$ is a new finding (21). Our XRF data, in line with the results of Harris et al. (21) on caries, confirm the presence of $\mathrm{Zn}$ and $\mathrm{Cu}$ in decayed dentin and reveals, for the first time, an increase in the concentration of these elements into pulp stones compared to physiological dentin.

$\mathrm{Zn}$ and $\mathrm{Cu}$ are essential trace elements for living organisms, taking part in many aspect of metabolism.

The higher concentration of elements in mineralized tissues is usually attributed to their presence in three 'compartments'. Zn may be found as a free element in solution $(19,20)$, it may be inserted within the apatite structure, or it may be coordinately bound to several organic molecules. Because our samples were dried before observation, the liquid phase was no longer present. $\mathrm{Zn}$ can substitute for no more than $5 \%$ of $\mathrm{Ca}$ in apatite crystal without inducing significant modifications to the lattice parameters (26), and its integration into apatite has been documented in various physiological or ectopic mineralization processes $(24,27,28)$. Previous studies have described the presence of $\mathrm{Zn}$ bound to metalloenzymes in bone ( 25 Gomez et al. 1999) and in dentin ( 19,20 Deymier-Black et al. 2014 ; Djomehri et al. 2015). In line with those previous results the occurrence of $\mathrm{Zn}$ and $\mathrm{Cu}$ in pulp stones might be secondary to the presence of various organic components such as metalloenzymes. Among the metalloenzymes potentially present in this tissue, the concomitant increase in both trace elements $\mathrm{Cu}$ and $\mathrm{Zn}$ could account for the presence of a Cu/Zn SODs, in an inflammatory context.

Dental caries is a multi-factorial infectious disease. It is a localized, destructive and progressive infection of dentin. When bacteria reach the dentin, they penetrate into the tubules and invade the odontoblastic cell process by diffusion (29). The pulphealing response to carious disease has been extensively investigated and is quite well understood. However, pulpal responses that are not related to caries, but to additional chemical or mechanical aggression, require a new perspective. The 
odontoblasts are the first line of defense and are involved in the initiation, development and maintenance of the pulp immune and inflammatory responses to dentin-invading pathogens (30).

Inflammation of the dental pulp is associated with the release of a wide variety of highly oxidative molecules known as reactive oxygen species (ROS) $(31,32)$. Host cells release these molecules during inflammatory processes (33). Excess production of ROS contributes to the pathogenesis of many diseases involving inflammation (34) and renders tissue susceptible to oxidative damage (35). In order to avoid excessive oxidative tissue damage caused by the cumulative load of ROS, their concentrations are controlled by various cellular defense mechanisms, including antioxidant enzymes such as catalase, glutathione peroxidase and superoxide dismutase (SOD) (33). More specifically, previous studies demonstrated an increase in the enzymatic activity of $\mathrm{Cu} / \mathrm{Zn}$ SODs in inflamed pulp when compared to healthy pulp (31). We therefore hypothesize that the increased concentration of $\mathrm{Cu}$ and $\mathrm{Zn}$ we observed in the present study within the carious dentin and the pulp calcifications might reflect the increased anti-oxidative action of $\mathrm{Cu} / \mathrm{Zn} \mathrm{SOD}$, probably secreted by odontoblasts or other local cells to control the oxidative state in the inflamed area.

We propose the following model of the pulpal mineralization mechanism. We suppose that pulp cells have the ability to mineralize at a basic level, but under physiological conditions this property would be inhibited. However, in an oxidative state promoted by repeated mild injury, odontoblasts (or other local cells) secrete $\mathrm{Cu} / \mathrm{Zn} \mathrm{SOD}$ and transmit a signal to the pulpal cells. In this context, pathophysiological interactions between odontoblasts and pulpal cells would release the inhibition of mineralization, resulting in calcification of pulp tissue.

\section{Conclusion}

In this study, we characterized the ultrastructure of pulp stones, identified the apatite phase, and demonstrated the presence of heavy chemical elements in the mineralized tissue. Challenged pulpal cells produce unstructured, mineralized matrices evidenced by abnormally high levels of $\mathrm{Zn}$ and $\mathrm{Cu}$. We hypothesize that the presence of high concentrations of $\mathrm{Cu}$ and $\mathrm{Zn}$ in pulp stones, which are not observed in physiological dentin, may be related to increased SOD enzyme activity, and that 
pulp stones appear in an inflammatory context. Under these conditions of oxidative stress, inhibition of mineralization in pulp cells would be lifted, leading to calcification of the pulp. 


\section{Figure legends}

Figure 1 : Scanning electron microscopy images (a-b : SE; c-g : BSE): a) Pulp stone (white bar : $500 \mu \mathrm{m})$, b) Higher magnification of pulp stone surface (white bar : $50 \mu \mathrm{m}$ ), c) Pulp stone section (white bar : $500 \mu \mathrm{m}$ ), d-f) Higher magnifications of section detail : tubular structures in blue boxed area (d) (white bar : $5 \mu \mathrm{m}$ ), concentric structures (e)

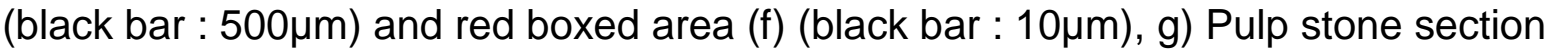
(white bar : $1 \mathrm{~mm}$ ) with measured points by EDS, h) EDS spectra of points of interest. Only points 1-4-5 provide significant $\mathrm{Zn}$ peak at $8.63 \mathrm{keV}$. Peaks at $8.40 \mathrm{keV}$ and 9.45keV are attributed to $\mathrm{Pt}(\mathrm{L} \alpha-\mathrm{M})$ and $\mathrm{Pt} \mathrm{LI}$ respectively.

Figure 2. 2D-X-ray diffraction patterns. (a) Healthy dentin. (b) Carious dentin. (c) Pulp stone. (d) Diffraction diagram obtained by radial intensity integration of the diffraction image of (a), (b) and (c). Shoulder (asterisk) is attributed to the (202) crystallographic direction.

Figure 3. X-ray fluorescence spectra of carious dentine, pulp stone and sound dentin. Contributions of $\mathrm{P}(\mathrm{Ka}=2.013 \mathrm{keV})$, atmospheric $\mathrm{Ar}(\mathrm{Ka}=2.958 \mathrm{keV}), \mathrm{Ca}(\mathrm{Ka}=$ $3.691 \mathrm{keV}, \mathrm{K} \beta=4.012 \mathrm{keV}), \mathrm{Cu}(\mathrm{K} \alpha=8.047 \mathrm{keV}), \mathrm{Zn}(\mathrm{K} \alpha=8.638 \mathrm{keV}, \mathrm{K} \beta=9.572$ $\mathrm{keV})$ and $\mathrm{Sr}(\mathrm{K} \alpha=14.165 \mathrm{keV})$. Note: peaks at $16.534 \mathrm{keV}$ and $17.479 \mathrm{keV}$ are Compton scattering and irradiation, respectively. Inset, a zoom between $7.5 \mathrm{keV}$ and $10 \mathrm{keV}$, in logarithmic units.

Figure 4. Mean values of the area ratio of fluorescence peaks of $\mathrm{Zn}$ and $\mathrm{Cu}$ versus $\mathrm{Ca}$ for six samples. Areas were obtained by fitting with MyPCA software. Each ratio shows the relative proportion of trace element (normalized by $\mathrm{Ca}$ ). Data are presented as the mean \pm S.D. ns: non-significant, ${ }^{\star} P<0.05,{ }^{\star \star} P<0.01,{ }^{\star \star \star} P<0.001$.

\footnotetext{
${ }^{1}$ Magloire H, Romeas A, Melin M et al. Molecular regulation of odontoblast activity under dentin injury. Adv Dent Res. 2001;15:46-50.

2 Couve E. Ultrastructural changes during the life cycle of human odontoblasts. Arch Oral Biol 1986;31:643-51.

${ }^{3}$ Simon S, Smith AJ, Lumley PJ et al. Molecular characterization of young and mature odontoblasts. Bone 2009; 45(4):693-703.

${ }^{4}$ Goldberg, M, Smith, AJ. Cells and extracellular matrices of dentin and pulp: a biological basis for repair and tissue engineering. Crit Rev Oral Biol Med 2004;15:13-27.

${ }^{5}$ Moss-Salentijin L, Hendricks-Klyvert MS. Calcified structures in the human dental pulps. J Endod 1988;14: 184-9.

${ }^{6}$ Chandler NP, Pitt Ford TR, Monteith BD. Coronal pulp size in molars: a study of bitewing radiographs. Int Endod J 2003;36:757-63.

${ }^{7}$ Arys A, Philippart C, Dourov N. Microradiography and light microscopy of mineralization in the pulp of undemineralized human primary molars. J Oral Pathol Med 1993;22:49-53.

${ }^{8}$ Luukko K, Kettunen P, Fristad I et al. Structure and functions of the dentin-pulp complex. In: Cohen S, Burns RC, eds. Pathways of the pulp. 10th ed. St. Louis: Mosby 2011; 494-7.
} 
${ }^{9}$ Kannan S, Kannepady SK, Muthu K et al. Radiographic assessment of the prevalence of pulp stones in Malaysians. J Endod 2015; 41:333-7.

${ }^{10}$ Johnson PL, Bevelander G. Histogenesis and histochemistry of pulpal calcification. J Dent Res 1956;35:714-22.

${ }^{11}$ Sayegh FS, Reed AJ. Calcification in the dental pulp. Oral Surg,Oral Med Oral Pathol 1968;25:873-2.

12 Mjör IA, Pindborg JJ. Histology of the human tooth. 1973 Copenhagen: Munksgaard, 61-2.

13 Trowbridge HO, Tewart JCB, Shapiro IM. Assessment of indurated, diffusely calcified human dental pulp. In: Proceedings of the International Conference of Dentin/Pulp Complex, Tokyo, 1996, Quintescence Publishing Co, p 297.

${ }^{14}$ Goga R, Chandler NP, Oginni AO. Pulp stones: a review. Int Endod J 2008;41:457-68.

15 Dessombz A, Lignon G, Picaut L, et al. Mineral studies in enamel, an exemplary model system at the interface between physics, chemistry and medical sciences, C. R. Chim., 2015; 10.1016/j.crci.2015.03.009 ${ }_{16}$ Dessombz A, Bazin D, Dumas P et al. Shedding Light on the chemical diversity of ectopic calcifications in kidney tissues: diagnostic and research aspects. PLoS ONE 2011;6(11):e28007.

17 Tomazic BB, Edwards WD, Schoen FJ. Physiochemical characterization of natural and bioprosthetic heart valve calcific deposits: implications for prevention. Ann Thorac Surg 1995;60:S322-7.

18 Zavgorodniy AV, Rohanizadeh R, Bulcock S et al. Ultrastructural observations and growth of occluding crystals in carious dentin. Acta Biomater 2008;4,1427-39.

${ }^{19}$ Stock SR, Deymier-Black AC, Veis A et al. Bovine and equine peritubular and intertubular dentin. Acta Biomater 2014;10(9):3969-77.

${ }^{20}$ Xue J, Zhang L, Zou L et al. High-resolution X-ray microdiffraction analysis of natural teeth. J Synch Rad 2008;15:235-8.

${ }^{21}$ Harris HH, Vogt S, Eastgate $\mathrm{H}$ et al. A link between copper and dental caries in human teeth identified by X-ray fluorescence elemental mapping. J Biol Inorg Chem 2008;13:303-6.

22 Solé VA, Papillon E, Cotte M et al. A multiplatform code for the analysis of energy-dispersive X-ray fluorescence spectra. Spectrochim Acta Part B 2007;62:63-8.

${ }^{23}$ Schroeder HA, Tipton IH, Nason AP. Trace metals in man: strontium and barium J Chronic Dis 1972;25:491-517.

${ }^{24}$ Deymier-Black AC, Veis A, Cai Z et al. Crystallographic texture and elemental composition mapped in bovine root dentin at the $200 \mathrm{~nm}$ level. Scanning 2014;36(2):231-40.

${ }^{25}$ Gomez S, Rizzo R, Pozzi-Mucelli M et al. Zinc mapping in bone tissues by histochemistry and synchrotron radiation-induced X-ray emission: correlation with the distribution of alkaline phosphatase. Bone 1999;25:33-8.

${ }^{26}$ Ren F, Xin R, Ge X et al. Characterization and structural analysis of zinc-substituted hydroxyapatites. Acta Biomater 2009;5:3141-9.

27 Dessombz A, Nguyen C, Ea HK et al. Combining $\mu$ X-ray fluorescence, $\mu$ XANES and $\mu$ XRD to shed light on Zn2+ cations in cartilage and meniscus calcifications. J Trace Elem Med Biol 2013;27:326-33.

${ }^{28}$ Sharif R, Thomas P, Zalewski P, Fenech M. The role of zinc in genomic stability. Mutat Res 2012;733:111-21.

${ }^{29}$ Love RM, Jenkinson HF. Invasion of dentinal tubules by oral bacteria. Crit Rev Oral Biol Med 2002;13:171-83.

${ }^{30}$ Farges JC, Keller JF, Carrouel F et al. Odontoblasts in the dental pulp immune response. J Exp Zool B Mol Dev Evol 2009;312B(5):425-36.

${ }^{31}$ Baumgardner KR, Sulfaro MA. The anti-inflammatory effects of human recombinant copper-zinc superoxide dismutase on pulp inflammation. J Endod 2001;27:190-5.

32 Duncan HF, Smith AJ, Fleming GJP et al. HDACi cellular effects, opportunities for restorative dentistry. J Dent Res 2011:90,:1377-88.

${ }^{33}$ Freeman BA, Crapo JD. Biology of disease: free radicals and tissue injury. Lab Invest 1982;47(5):412-26.

34 Nussler AK, Billiar TR. Inflammation, immunoregulation, and inducible nitric oxide. J Leukoc Biol 1993;54:171-8.

35 Cerutti PA. Prooxidant states and tumor promotion. Science 1985;227:375-81. 